DOI: $10.17805 /$ zpu.2016.1.9

\title{
Участие молодежи в инновационном развитии экономики страны (на примере Республики Татарстан)
}

\author{
И. Л. САВЕЛЬЕВ, И. Р. НАСЫРОВ \\ (АППАРАТ ПРЕЗИДЕНТА РЕСПУБЛИКИ ТАТАРСТАН, КАЗАНЬ)
}

Инновационный потенциал новых поколений сегодня включается в число наиболее значимых ресурсов социально-экономического и культурного развития. В статье рассматриваются вопросы участия молодежи в инновационном развитии страны на примере реализации государственной молодежной политики и поддержки инноваций в Республике Татарстан (субъекте Российской Федерации). Исследуется привлечение молодежи к инновационному развитию экономики, прикладной научно-исследовательской работе, внедрению высоких технологий в производство.

Основной вектор вовлечения молодежи в инновационное развитие экономики задается на федеральном уровне. В России принята Стратегия инновационного развития Российской Федерации на период до 2020 г., а также реализуются общероссийские программы поддержки молодежного предпринимательства и инноваций, включая развитие инновационного комплекса «Сколково». В регионах деятельность государственных органов по выявлению и продвижению инициативной и талантливой молодежи реализуется с разной степенью эффективности.

Авторы отмечают, что в основе развития инновационной экономики Республики Татарстан и вовлечения в нее молодежи лежит программно-целевой подход. В республике принята Стратегия социально-экономического развития региона до 2030 г., регулярно актуализируются целевые программы, направленные на достижение поставленных целей. C начала 2000-х годов целенаправленно развивается инновационная производственная инфраструктура, формируются институты поддержки предпринимательства. С учетом демографической ситуации и запросов развивающейся экономики особое внимание уделяется проблеме накопления человеческого капитала. В 2006 г. в Татарстане была запущена первая региональная программа грантов «Алгарыш», направленная на 
подготовку кадров в российских и зарубежных образовательных учреждениях. По линии региональных, а также муниципальных органов власти и ведомств реализуются меры стимулирования инновационной научно-исследовательской деятельности. Оказывается организационная и финансовая поддержка молодежным организациям, ориентированным на творческую самореализацию и вовлечение в инновационную сферу молодых граждан. Участие молодежи в инновационной деятельности представляет обоюдный интерес для государства и молодого поколения. Реализация творческого потенциала молодежи требует системной поддержки. В основе динамичного развития инновационной экономики Татарстана, успешного формирования инновационного человеческого капитала лежит эффективная целенаправленная работа органов власти региона.

Ключевые слова: инновации; молодежная политика; поддержка талантливой молодежи; инновационная инфраструктура; развитие территорий; Татарстан; молодежь Татарстана; социология молодежи

\section{ВВЕАЕНИЕ}

$\mathrm{P}$ еалии мировых әкономических и социально-политических процессов, необходимость укрепления российского государства обусловливают приоритетность задачи инновационного развития страны и ее регионов. Реализация данной задачи представляется невозможной без вовлечения в этот процесс молодежи, составляющей около четверти населения страны.

По оценке И. М. Ильинского, «молодежь - это жизненная сила общества, сгусток энергии, нерастраченных интеллектуальных и физических сил, требующих выхода. В молодости человек наиболее способен к творческой деятельности, к формулировке эвристических подходов, максимально работоспособен» (Ильинский, 2001: 81-82).

Как отмечают современные исследователи, «инновационный потенциал новых поколений сегодня включается в развитых странах в число наиболее значимых ресурсов социального и культурного развития» (Ауков В., Ауков С., Погорский, 2014: 7). Естественная ассоциация молодежи с инновациями объясняется тем, что «молодежи чтото легче придумать, чем найти в социокультурной копилке прошлого (в виде прецедента, ранее сформулированной идеи, разработанной технологии и т. п.) <...> ее не сбивает ранее усвоенное знание, она свободна от его логики и неоспоримости, ей легче, следовательно, идти по непроторенным тропам: она не знает, какие проторены» (там же: 11). Проблемы молодежи и инновационного потенциала подробно описываются в работах представителей научной школы Московского гуманитарного университета (там же: 7).

Вопросы реализации стратегического ресурса молодежи как основного источника инноваций, важнейшего фактора перемен в контексте осуществления социальной политики на рынке образовательных услуг и молодежном рынке труда Ставропольского края представлены в работе Е. В. Смирновой и С. В. Митрофановой (Смирнова, Митрофанова, 2014). Формирование государственной молодежной политики на региональном уровне, включающей поддержку развития творческого потенциала молодежи, представлены в ряде работ других отечественных исследователей (Бариев, 2009; Московцева, 2011; Уразметова, Хисматуллин, 2015; Хисматуллин, 2014).

Мы исследуем привлечение молодежи к инновационному развитию экономики, прикладной научно-исследовательской работе, внедрению высоких технологий в производство, основываясь на анализе опыта Республики Татарстан. Аанная тематика относится к направлению изучения инновационного потенциала молодежи, при этом не затрагиваются отдельные вопросы социального характера, в частности участие молодежи в общественно-политической жизни. 
ВОВАЕЧЕНИЕ МОАОДЕЖИ В ИННОВАЦИОННУЮ АЕЯТЕАЬНОСТЬ

Современную молодежь, большую часть которой составляет поколение, сформировавшееся в постсоветские годы, отличает прагматичное отношение к жизни. Аейственность государственной молодежной политики во многом зависит от создания условий для реализации творческого и трудового потенциала молодежи, личностного роста, создания социальных лифтов.

Стратегия инновационного развития Российской Федерации на период до 2020 года, принятая 8 декабря 2011 г., относит к первоочередным задачам создание эффективных материальных и моральных стимулов для «притока... творческой молодежи в сектора экономики, определяющие ее инновационное развитие» (Распоряжение Правительства ..., 2012: Электронный ресурс). Координация в области популяризации в обществе научной и инновационной деятельности возлагается не только на Федеральное агентство по делам молодежи, но и на целый ряд других федеральных структур, среди которых Министерство образования и науки Российской Федерации, Министерство связи и массовых коммуникаций Российской Федерации, Министерство экономического развития Российской Федерации, автономная некоммерческая организация «Агентство стратегических инициатив по продвижению новых проектов». Особая роль молодежной составляющей в инновационном развитии страны подчеркивается выделением данного вопроса в отдельный раздел стратегии «Молодежь и инновации».

$\mathrm{K}$ наиболее эффективным методам достижения поставленных целей можно отнести развитие системы профильных образовательных учреждений по отдельным отраслям знаний, охватывающих талантливую молодежь с школьных лет, расширение грантовой поддержки обучения и реализации молодежных проектов, курс на систематическое обновление кадрового состава на предприятиях и в органах власти, научно-исследовательских учреждениях. Важным элементом является создание инновационных структур, ориентированных на молодежь: бизнес-инкубаторы, технопарки и другие формы поддержки инновационно-предпринимательской деятельности, в том числе при вузах.

Особая роль в этом предназначается первому строящемуся в современной России инновационному центру «Сколково», основными градообразующими элементами которого являются технопарк и Сколковский институт науки и технологий. Проектом предусмотрено проживание в арендном жилье 20 тыс. человек, общее число работающих с учетом приезжающих из Москвы и области составит около 30 тыс. человек. Хотя концепция «Сколково» позиционирует его как научно-технологический инновационный комплекс по разработке и коммерциализации новых технологий без явного акцента на молодежную составляющую, очевидно, что значительная часть работающих и обучающихся здесь людей именно молодого возраста.

Аля стимулирования активной молодежи, обучения и консультационно-методической помощи исследователям и начинающим предпринимателям успешно используются такие формы, как проведение специализированных смен в летних молодежных лагерях (форумы федерального и регионального уровней «Селигер», «іВолга»), программы поддержки молодежного предпринимательства и инноваций, реализуемые на федеральном уровне («Ты - предприниматель», «УМНИК», «Старт», «Зворыкинский проект», Всероссийский инновационный конвент и др.).

Что касается работы на уровне субъектов Федерации то, по мнению отечественных исследователей, в регионах уровень развития молодежной политики и ее эффективность существенно различаются, отсутствует комплексная система выявления и про- 
движения инициативной и талантливой молодежи (Когай, Атанасов, 2013: 2). В 2012 г. бюджетное финансирование реализации молодежной политики в субъектах Российской Федерации в расчете на одного человека в возрасте 14-30 лет различалось более чем в 28 раз (Антипина, 2014: 117).

Важной составляющей государственной политики, реализуемой на региональном уровне, является поддержка инновационной предпринимательской деятельности. При этом существуют объективные, общие для данной сферы проблемы, часть из которых можно решить только на федеральном уровне. Например, если результатом внедрения инновационной разработки становится предоставление новой услуги, то может потребоваться ее регламентация и лицензирование.

К объективным проблемам развития инновационного предпринимательства относятся повышенные риски, проблемы получения стартового капитала, продвижения новой продукции на рынках, поиска заинтересованных партнеров. Молодые предприниматели должны уметь ориентироваться на рынке венчурного капитала, строить отношения с потенциальными инвесторами, коммерсантами и потребителями, решать вопросы технико-экономической экспертизы, выстраивать производственные цепочки и сети сбыта, заниматься маркетингом и рекламой. В этой части могут быть полезными различные тренинги, коммуникация с коллегами, участие в программах поддержки молодежного предпринимательства.

\section{ОПЫТ РЕСПУБАИКИ ТАТАРСТАН}

Системный подход к развитию инновационной деятельности в Республике Татарстан обеспечивается формированием соответствующей нормативно-правовой базы. В 2004 г. Кабинетом министров (Правительством) Республики Татарстан была принята Программа инновационного развития Республики Татарстан до 2010 г., определившая первоочередные задачи государственных, частных и общественных органов в области инновационной деятельности. В 2008 г. Указом Президента Республики Татарстан утверждена Стратегия развития научной и инновационной деятельности в Республике Татарстан до 2015 г.; в 2010 г. принят Закон Республики Татарстан «Об инновационной деятельности в Республике Татарстан». Впоследствии постановлением республиканского правительства от 15 октября 2011 г. № 857 была утверждена концепция Аолгосрочной целевой программы «Развитие рынка интеллектуальной собственности в Республике Татарстан на 2012-2020 годы».

С целью обнародования ключевых аспектов формирования и проведения государственной инновационной политики в Республике Татарстан, координации деятельности субъектов инновационной деятельности, обеспечения эффективного государственного регулирования инновационной сферы постановлением Кабинета министров Республики Татарстан принят «Инновационный меморандум Республики Татарстан на 2014-2016 годы».

Государственная программа «Стратегическое управление талантами в Республике Татарстан на 2015-2020 годы» утверждена постановлением Кабинета министров Республики Татарстан от 3 декабря 2014 г. № 943. Цель программы - обеспечение развертывания преемственной системы развития интеллектуально-творческого потенциала детей, молодежи и стратегическое управление талантами в интересах инновационного развития Республики Татарстан. Площадкой коммуникаций и взаимодействия всех участников, адресатов и субъектов данной программы должна стать образовательная платформа «Казанский открытый университет талантов 2.0». 
В июне 2015 г. была принята Стратегия социально-экономического развития Республики Татарстан до 2030 года (далее - Стратегия). В число трех ее приоритетов вошло формирование и накопление человеческого капитала, определенное в документе как «магнит для лучших». В качестве ключевого вызова для инновационного экономического развития названо уменьшение численности молодежи. По оценке разработчиков программы, в ближайшие годы численность молодых специалистов, выходящих на рынок труда республики, по демографическим причинам уменьшится примерно на $40 \%$. Согласно Стратегии реализация инновационной политики опирается на унифицированный подход, основанный на формировании «экосистемы инноваций», представляющей собой совокупность взаимоотношений всех элементов сферы инновационной деятельности, характеризующих восприимчивость государства и общества к инновациям. Образование определено как основа развития Татарстана (Об утверждении Стратегии ..., 2015: Электронный ресурс).

Инновационная инфраструктура в регионе стала активно создаваться с 2002 г., пионером ее стал казанский технопарк «Идея». В настоящее время в Татарстане действуют две особые экономические зоны: «Алабуга» и «Иннополис», а также технопарки (среди которых видное место занимает технопарк в сфере высоких технологий «ИТ-парк»), технополисы, индустриальные парки для субъектов малого и среднего предпринимательства, входящие в состав технопарков и действующие самостоятельно бизнес-инкубаторы, инжиниринговые центры, институты венчурного финансирования.

Во взаимодействии с российскими и зарубежными партнерами ведется работа по развитию нано- и биотехнологий, производству композитных материалов, лазерных технологий, робототехники и др. Если развитие данных направлений является следствием целенаправленной работы по привлечению инноваций в республику, то направление «информационные технологи» для Татарстана имеет богатые традиции, которыми можно объяснить успешную реализацию крупных проектов, получивших российское и международное признание. Аостаточно отметить создание электронного правительства Республики Татарстан, в составе которого межведомственная система электронного документооборота, с 2008 г. связывающая органы власти, ведущие предприятия и организации республики, а также портал государственных услуг, интернет-порталы республиканского правительства и муниципальных образований, объединяющие несколько сотен сайтов. Прорыв в ИТ-сфере объясняется наличием в Татарстане мощной научно-образовательной базы, активностью высококвалифицированных молодых специалистов в сочетании с серьезной финансовой и организационной поддержкой правительства республики.

Представляя инновационную инфраструктуру Татарстана, необходимо особо выделить «Иннополис» - проект создания нового города рядом с Казанью, ориентированного на привлечение молодых высококвалифицированных специалистов. Перспективная численность населения Иннополиса - 155 тыс. человек, включая 60 тыс. специалистов в сфере высоких технологий. Предполагаемый средний возраст жителей - 27 лет. Мастер-план будущего города, который все чаще называют будущей ИТ-столицей России, разработан в первой половине 2012 г. архитектурно-планировочным бюро RSP Architects Planners \& Engineers под руководством архитектора Ииу Тай Кера, создавшего образ современного Сингапура. Старт строительству был дан в июне 2012 г., а запуск первой очереди, рассчитанной на 5 тыс. рабочих мест, состоялся спустя ровно три года, в июне 2015 г., с участием премьер-министра Российской Федерации А. А. Медведева и временно исполняющего обязанности Президента Рес- 
публики Татарстан Р. Н. Минниханова (Высокие технологии ..., 2015: Электронный ресурс). Привлечению резидентов способствует статус особой экономической зоны, обеспечивающий льготный режим налогообложения.

Еще одной отличительной особенностью Иннополиса, характеризующей его именно как город, рассчитанный на привлечение специалистов для длительного проживания, является концепция предоставления сотрудникам компаний-резидентов арендного жилья различного уровня (от многоквартирных домов до таунхаусов и коттеджей) с правом последующего выкупа.

В дополнение к бизнес-инфраструктуре, на первом этапе создаваемой в формате технопарка, в декабре 2012 г. был открыт Университет Иннополис - первый в России университет, специализирующийся в области информационных технологий, созданный в партнерстве с Университетом Карнеги - Меллон (Carnegie Mellon University, CШША).

Важным драйвером развития Иннополиса может стать создание отечественного базового программного обеспечения. В апреле 2015 г. Минкомсвязи России утвердило план импортозамещения программных продуктов, в соответствии с которым в большинстве сегментов российского корпоративного рынка через 10 лет отечественное программное обеспечение должно занять не менее 50\% (Кантышев, 2015: Электронный ресурс).

Вкладывая значительные средства из федерального и республиканского бюджета в строительство Иннополиса, органы власти фактически берут на себя дополнительные обязательства по обеспечению заполненности создаваемой бизнес-инфраструктуры. У Татарстана появляется дополнительная мотивация в привлечении в республику инновационных проектов. Это будет способствовать решению задачи поддержки инновационных проектов, обеспечивая востребованность инноваций со стороны государства.

Реальные проблемы кадрового обеспечения инновационных производств молодыми специалистами можно рассмотреть на примере особой экономической зоны (ОЭ3) «Алабуга», которая имеет статус крупнейшей ОЭЗ промышленно-производственного типа России и ключевого центра привлечения инвестиций и внедрения инновационных технологий в Татарстане. В ее составе 45 компаний-резидентов (на середину 2015 г.), их число постоянно растет. Производство данной ОЭЗ составляет $70 \%$ производства всех ОЭЗ страны. Открываемые производственные мощности современных совместных предприятий ОЭЗ «Алабуга» определяют соответствующие кадровые запросы. По оценке руководства ОЭ3, на $80 \%$ востребован производственный персонал, только 13\% вакансий составляют инженеры, $7 \%$ - коммерческий персонал (Афанасьев, Идиятуллин, 2012: Электронный ресурс). Причем если вначале при обсуждении кадровых проблем на совещания приглашались в основном руководители республиканских вузов, то впоследствии в эту работу были внесены существенные коррективы. В частности, для решения задачи подготовки специалистов, ориентированных на компании-резиденты, на базе Елабужского политехнического колледжа был открыт ресурсный центр подготовки специалистов, который проводит подготовку по 15 наиболее востребованным на сегодняшний день специальностям. В течение 2014 г. с этой целью удалось привлечь 20 заведений высшего и среднего профессионального образования не только в Елабуге, но и в соседних городах.

Ситуация с инженерными специальностями имеет две особенности. Во-первых, компании-резиденты на период строительства и пусконаладки производства пригла- 
шают зарубежных специалистов, а российские специалисты привлекаются уже на работающие заводы. Кроме того, было отмечено, что отечественные вузы готовят специалистов по устаревшим программам, в то время как новые производства в «Алабуге» создаются по западным технологиям, которые существенно отличаются от изучаемых в учебных заведениях. Необходимость организации дополнительного обучения молодых специалистов приводит к значительному росту затрат предприятий. Это способствовало возникновению проблемы перехода подготовленных специалистов с одного на другое предприятие внутри ОЭЗ. С целью әффективного решения задач обучения специалистов для компаний-резидентов в профильных республиканских вузах данные вопросы возложены на проректоров, взаимодействующих с кадровыми службами особой экономической зоны. Разработка профессиональных стандартов и совместные планы подготовки специалистов ориентированы на решение указанных проблем (Особой экономической зоне ..., 2015: Электронный ресурс).

Характеризуя проблемы создания инновационных производств, следует добавить, что до постановки масштабной государственной задачи развития импортозамещения свыше 50\% всех инновационных расходов в Татарстане приходилось на приобретение инновационной техники и технологий и лишь $20 \%$ - на ее создание на базе республиканского научно-технического потенциала (Стратегия развития ... , 2008: Электронный ресурс). Кроме того отсутствовали экономические предпосылки для развития инновационной сферы, не гарантирующей быстрого возврата вложенных средств, также не был сформирован платежеспособный спрос на инновационные технологии и товары.

Важным направлением реализации творческого потенциала молодежи является совершенствование системы образования и научно-исследовательской деятельности. Татарстан обладает значительным научно-образовательным потенциалом, основы которого были заложены еще в советские годы. Вместе с тем на современном этапе возникли определенные проблемы в данной сфере. Так, в Стратегии развития научной и инновационной деятельности в Республике Татарстан до 2015 года было отмечено, что наибольшая текучесть научных кадров наблюдается в возрастной группе до 35 лет. Аспирантура стала терять основную роль обеспечения перспективного кадрового потенциала для научной и научно-педагогической деятельности (там же).

Аля стимулирования талантливой молодежи в Татарстане широко используются грантовые механизмы, хорошо зарекомендовавшие себя в мировой и российской практике. Пожалуй, наиболее интересен опыт реализации программы грантов Правительства Республики Татарстан «Алгарыш» (в переводе с татарского - «Прогресс»), направленной на обучение и стажировку молодежи в российских и зарубежных образовательных и научных организациях. Это первая региональная программа такого рода в России, инициированная в 2006 г. занимавшим в то время пост премьер-министра Республики Татарстан Р. Н. Миннихановым.

Гранты выделяются на конкурсной основе разным категориям татарстанцев, от студентов и аспирантов до профессорско-преподавательского состава, учителей, работников физкультуры, спорта и туризма. При этом на подготовку и стажировку специалистов, аспирантов и молодых ученых до 35 лет используется около $70 \%$ ежегодного бюджета программы, достигающего 100 млн руб. В последние годы были повышены требования к соискателям гранта в части выбора учебного заведения и подтверждения уровня владения иностранным языком. Конкурсные процедуры и принимаемые решения детально освещаются на сайте программы. 
В 2015 г. было выделено 200 грантов. Всего же с 2006 г. в рамках программы «Алагрыш» были поддержаны 3410 соискателей и проектных групп. Одним из условий получения гранта является трудоустройство и осуществление трудовой деятельности в Татарстане не менее трех лет. С целью более эффективного использования потенциала выпускников программы в 2012 г. введена практика подготовки комплексных групп под конкретные инновационные проекты. В 2014 г. появились новые категории: «Молодые специалисты», а также «Авойные дипломы» (совместные проекты татарстанских вузов с зарубежными университетами) (Более двухсот человек ..., 2014: Электронный ресурс). В 2015 г. на средства программы для проведения занятий в татарстанских вузах стали приглашаться ведущие ученые с мировым именем.

Татарстан по праву считается одним из ведущих российских центров образования и науки и готов обеспечить хорошие возможности для обучения и научно-исследовательской работы. В Казани действуют Академия наук Татарстана, институты Российской академии наук, десятки НИИ различной отраслевой направленности. Из 27 татарстанских вузов - 3 имеют статус федеральных университетов: Казанский (Приволжский) федеральный университет, Казанский национальный исследовательский технологический университет, Казанский национальный исследовательский технический университет им. А. Н. Туполева. Всего в вузах республики обучается около 170 тыс. студентов по самым различным направлениям от фундаментальных математики и физики, широкого спектра прикладных специальностей, ориентированных на диверсифицированную региональную экономику, до культуры и туризма. Хороший уровень подготовки специалистов подтверждается не только многолетней репутацией вузов, но и высокими местами в рейтинге российских университетов (Казанский (Приволжский) федеральный университет стабильно входит в топ-20 лучших вузов России по рейтингу агентства RAEX ( «Эксперт PA»)).

Осуществляемое в ходе реформирования высшей и научной школы включение в состав Президиума Академии наук Татарстана и попечительские советы вузов представителей крупнейших республиканских предприятий направлено на установление конструктивных взаимоотношений с основными работодателями, заказчиками научно-исследовательских работ, обеспечение подготовки специалистов, востребованных современной экономикой республики.

Аля стимулирования наиболее талантливых студентов и аспирантов в Татарстане используется система специальных государственных и именных стипендий, являющаяся существенным дополнением к российским стипендиальным программам.

Аля аспирантов, адъюнктов, студентов и курсантов, обучающихся в государственных и частных образовательных организациях в Республике Татарстан, Указом Президента Республики Татарстан от 3 марта 1998 г. № УП-168 учреждены 90 специальных государственных стипендий Республики Татарстан. Кроме того, для обучающихся в татарстанских вузах победителей и призеров всероссийских и международных олимпиад школьников учреждено 100 стипендий Президента Республики Татарстан, в том числе 50 стипендий для студентов, постоянно проживающих на территории $\mathrm{Pe}$ спублики Татарстан. Ежегодно в Казанском Кремле проходит встреча Президента Республики Татарстан с лауреатами республиканских государственных стипендий, где в формате диалога ведется обмен мнениями по актуальным проблемам студенческой молодежи.

С целью привлечения талантливой молодежи в сферу науки студентам республиканских вузов присуждаются 15 стипендий Академии наук Татарстана. Аля школьников, 
студентов и аспирантов, занимающихся научно-исследовательской деятельностью в области городского хозяйства, социальной сферы и молодежной политики столицы Татарстана, с 1994 г. ежегодно присуждаются 38 именных стипендий мәра г. Казани. В 2014 г., объявленном Годом культуры, стипендиатами стали 30 воспитанников музыкальных и художественных школ (Именные стипендии ..., 2014: Электронный ресурс).

Грантовая поддержка и социальные меры поощрения активно используются Министерством по делам молодежи и спорту Республики Татарстан. С 2008 г. молодежными организациями было представлено более 2100 проектов по 8 номинациям, 650 проектов получили гранты по линии министерства (Аоклад министра ... , 2014: Электронный ресурс). Указанные проекты охватывают весь спектр молодежной политики, включая и представленные Региональным молодежным общественным движением молодых ученых и специалистов Республики Татарстан.

С целью стимулирования инновационной научно-исследовательской деятельности, привлечения молодежи к техническому творчеству, создания условий для внедрения в экономику Республики Татарстан инновационных технологий, развития наукоемких производств Академия наук Республики Татарстан и Государственная некоммерческая организация «Инвестиционно-венчурный фонд Республики Татарстан» проводят ежегодный конкурс «Пятьдесят лучших инновационных идей для Республики Татарстан», который в 2015 г. состоялся в 11-й раз. С 2005 г. Российская ассоциация венчурного инвестирования и Инвестиционно-венчурный фонд Республики Татарстан проводят Казанскую венчурную ярмарку, включающую экспозицию инновационных компаний и конгрессный блок, в котором проходят тематические мероприятия. В 2015 г. из 38 инновационных проектов, отобранных для включения в экспозицию ярмарки, 27 были представлены вузами республики (В Казани открылась ... , 2015: Электронный ресурс).

Реализации идей творческой молодежи, проживающей в Татарстане, способствует проведение Республиканского молодежного форума, среди площадок которого в 2015 г. были: «Молодежная наука и инновации», «Ты - предприниматель», «Информационный поток», «Архитектура и молодежная городская среда» и др. Проводимый с 2011 г. форум является инновационной площадкой, на которой любой молодой человек или команда могут продемонстрировать свой талант, активность, найти единомышленников и получить общественную и государственную поддержку.

Подтверждением высокого уровня вовлечения молодежи в инновационную сферу стало проведение Министерством иностранных дел Российской Федерации в апреле 2013 г. в Казани Международного молодежного форума российских соотечественников «Молодежь, наука, инновации», объединившего представителей молодежного актива русскоязычных диаспор из 44 стран мира.

Существенный вклад в работу с одаренными детьми вносит Татарстанский республиканский молодежный общественный фонд «Сэлэт» (в переводе с татарского языка - «талант», «способность»). Первые проекты «Сэлэт» стартовали в 1994 г. в формате летнего лагеря для детей, интересующихся информационными технологиями. В настоящее время разнообразные проекты и молодежные лагеря «Сэлэт» объединяют тысячи молодых людей в Татарстане и за его пределами, содействуя раскрытию личностных качеств, социальному и профессиональному становлению творчески одаренных личностей.

В Татарстане набирают популярность соревнования по робототехнике, проводимые также и на муниципальном уровне. «ИТ-парки» Казани и Набережных Челнов 
приглашают школьников в «ИТ-лагеря» iLand, проводятся конкурсы «ИТ-чемпион». В целях поощрения победителей ежегодного открытого командного турнира по программированию среди студентов и школьников Республики Татарстан Указом Президента Республики Татарстан от 31 марта 2010 г. № УП-182 учреждены премии Президента Республики Татарстан.

В рамках проекта «Национальная система мотивации детей к всестороннему развитию», разработанного Агентством стратегических инициатив (АСИ) с целью заинтересовать школьников техническими профессиями, в Татарстане планируется открыть детский технопарк. С учетом специфики әкономических отраслей республики предполагается предоставлять детям возможность попробовать себя в роли авиаконструктора, нефтяника, биолога.

Привлечению детей к естественным наукам способствуют традиционные форматы работы с молодежью, такие как создание интерактивных музеев (в 2005 г. в Казанском Кремле открыт музей естественной истории Татарстана, имеющий 800 тыс. уникальных әкспонатов и экспозиций) и центров детского творчества, например, открытый в Казани интерактивный научный центр для детей и взрослых «Аом занимательной науки и техники». В 2013 г. на базе астрономической обсерватории Казанского (Приволжского) федерального университета начал работу планетарий, оборудованный современной наблюдательной и проекционной техникой. Стоимость создания этого центра составила порядка 300 млн руб.

В 2012 г. по инициативе Президента Республики Татарстан Р. Н. Минниханова на территории Аеревни Универсиады в Казани был открыт лицей-интернат «ІТ-лицей КФУ», рассчитанный на обучение и проживание 360 детей 7-11-х классов. В 2013 г. в поселке Аубровка, рядом с Казанью, открыл свои двери специализированный лицейинтернат с углубленным изучением химии для интеллектуально одаренных учащихся 7-11-х классов, готовый принять 140 детей. Обучение в лицее ведется по химико-биологическому и физико-химическому направлениям. Заметим также, что в 2011 г. в селе Актаныш была открыта гуманитарная гимназия-интернат для одаренных детей с акцентом на углубленную лингвистическую подготовку.

В настоящее время системная работа с молодежью осуществляется в рамках ведомственной подпрограммы «Молодежь Татарстана на 2014-2016 годы», среди задач которой поиск, поддержка одаренных детей и молодежи, создание условий для развития их интеллектуального и творческого потенциала.

Позитивный опыт Республики Татарстан, который на основе динамичного развития экономики и инфраструктуры, продвижения модели мирного межэтнического и межкультурного сосуществования предлагает молодым россиянам возможности Аля самореализации, также представляет интерес с точки зрения воспитательно-образовательной работы. В июне 2015 г. комиссия Общественной палаты РФ по развитию общественной дипломатии и поддержке соотечественников за рубежом и Российский союз молодежи предложили правительству ввести в учебный план обязательные экскурсии и поездки детей по регионам России. Инициаторы проекта включили Казань в карту мест на территории России, в которых должен побывать каждый школьник (Елкина, 2015: Электронный ресурс).

\section{ЗАКАЮЧЕНИЕ}

Участие молодежи в создании инновационной экономики представляет обоюдный интерес для государства и молодого поколения. Государство решает актуальные 
задачи экономической модернизации, повышения конкурентоспособности в условиях глобализации, ответа на вызовы современного мира, опираясь на наиболее активную и мобильную часть населения. Молодежь получает возможность продуктивной самореализации, успешного вхождения в общественную жизнь, получения профессионального и трудового опыта при серьезной поддержке государства.

Очевидно, что создание производственной и бизнес-инфраструктуры для реализации инновационных проектов, организационное содействие на этапе привлечения инвесторов, внедрения и коммерческого продвижения новых технологий, обучение и информационная поддержка молодых исследователей и предпринимателей требуют весьма серьезных ресурсов, предоставить которые можно только в рамках осуществления целенаправленной государственной политики.

Среди ожидаемых результатов данной работы обычно указываются увеличение доли инновационной продукции в валовом внутреннем продукте и увеличение доли молодых людей, участвующих в проектах и программах поддержки талантливой молодежи и инновационном предпринимательстве. Однако за этими формальными показателями стоит решение совокупности важнейших задач, которые трудно измерить цифрами: от повышения конкурентоспособности и укрепления суверенитета государства до формирования новой интеллектуальной элиты страны или преодоления негативных и потребительских тенденций в моделях поведения молодежи. Содействие становлению форм самоорганизации активной молодежи, реализации ее творческих идей, вхождения в науку или бизнес направлено на решение стратегических долгосрочных задач социально-экономического развития.

Решение комплекса данных проблем возможно только при конструктивном взаимодействии органов власти, гражданского общества, политиков, ученых и творческой интеллигенции в рамках единой стратегии реализации национальных интересов.

В основе развития инновационной деятельности в Республике Татарстан в целом лежит комплексный программно-целевой подход. Особое внимание уделяется вопросам накопления человеческого капитала, участию молодежи в решении актуальных задач регионального развития. Среди основных направлений работы - создание инновационной производственной инфраструктуры, институтов поддержки предпринимательства, реформирование системы образования, разнообразные меры поддержки творческой молодежи, деятельности молодежных организаций. Последовательность в реализации поставленных целей обеспечивается включением их в список приоритетных задач развития Татарстана, совершенствованием и повышением әффективности системы государственного управления с учетом передового мирового опыта, политической и социально-экономической стабильностью в регионе.

\section{СПИСОК АИТЕРАТУРЫ}

Антипина, Н. А. (2014) Молодежная политика в России и за рубежом // Академический вестник ТГАМЭУП. № 2 (28). С. 115-122.

Афанасьев, С., Идиятуллин, А. (2012) Резиденты «Алабуги» перекупают кадры друг у друга [Электронный ресурс]// Аеловая электронная газета «Бизнес Online». 11 апреля. URL: http:// business-gazeta.ru/text/57634/ [архивировано в WebCite] (дата обращения: 17.06.2015).

Бариев, М. М. (2009) Молодежная политика в Республике Татарстан // Вестник Научного центра безопасности жизнедеятельности детей. № 1. С. 108-109.

Более двухсот человек в этом году получили гранты по программе Правительства РТ «Алгарыш» (2014) [Электронный ресурс]// Министерство образования и науки Республики Татар- 
стан. 23 октября. URL: http://mon.tatarstan.ru/rus/index.htm/news/349859.htm [архивировано в WebCite] (дата обращения: 17.06.2015).

В Казани открылась XV Российская и X Казанская венчурная ярмарка (2015) [Электронный ресурс]// Инвестиционно-венчурный фонд Республики Татарстан. 24 апреля. URL: http:// ivf.tatarstan.ru/rus/index.htm/news/422195.htm [архивировано в WebCite] (дата обращения: 17.06.2015).

Высокие технологии пропишутся в Татарстане (2015) [Электронный ресурс]// Казанские ведомости. № 81. 10 июня. URL: http://kazved.ru/article/61600.aspx [архивировано в WebCite] (дата обращения: 17.06.2015).

Аоклад министра по делам молодежи и спорту Республики Татарстан Владимира Александровича Цеонова на заседании Коллегии Министерства по делам молодежи и спорту Республики Татарстан «Опыт и перспективы реализации государственной молодежной политики в Республике Татарстан», посвященной 20-летию реализации государственной молодежной политики в Республике Татарстан (2014) [Электронный ресурс]// Министерство по делам молодежи и спорту Республики Татарстан. 11 декабря. URL: http://mdms.tatarstan.ru/rus/file/pub/pub_ 283868.doc [архивировано в WebCite] (дата обращения: 17.06.2015).

Елкина, М. (2015) В школьную программу предлагают включить обязательные путешествия [Электронный ресурс] // Известия. 9 июня. URL: http://izvestia.ru/news/587435 [архивировано в WebCite] (дата обращения: 17.06.2015).

Ильинский, И. М. (2001) Молодежь и молодежная политика. М. : Голос. 696 с.

Именные стипендии мәра Казани вручили в столице Татарстана (2014) [Электронный ресурс]// ИА «Татар-информ». 24 декабря. URL: http://tatar-inform.ru/news/2014/12/24/435825/ [архивировано в WebCite] (дата обращения: 17.06.2015).

Кантышев, П. (2015) Аогнать и перегнать за 10 лет [Электронный ресурс]// Ведомости. 5 апреля. URL: http://vedomosti.ru/newspaper/articles/2015/04/05/dognat-i-peregnat-za-10-let [apхивировано в WebCite] (дата обращения: 17.06.2015).

Когай, Е. А., Атанасов, А. Г. (2013) Социальное проектирование в региональной молодежной политике [Электронный ресурс]// Ученые записки. Электронный научный журнал Курского государственного университета. № 4 (28). C. 271-277. URL: http://scientific-notes.ru/pdf/ 033-039.pdf [архивировано в WebCite] (дата обращения: 17.06.2015).

Ауков, В. А., Ауков, С. В., Погорский, Э. К. (2014) Инновационный потенциах новых поколений и молодежная политика на современном этапе развития общества // PolitBook. №2. C. 6-18.

Московцева, Е. А. (2011) Молодежная политика на региональном уровне // Ученые заметки ТОГУ. Т. 2. № 1. С. 46-52.

Об утверждении Стратегии социально-экономического развития Республики Татарстан до 2030 года : Закон Республики Татарстан № 40-3РТ от 17 июня 2015 г. (2015) // Портал правовой информации Республики Татарстан. 17 июня. URL: http://pravo.tatarstan.ru/rus/gossov/zakon.htm/?npa_id=4431 [архивировано в WebCite] (дата обращения: 18.06.2015).

Особой экономической зоне требуются «спецы» (2015) [Электронный ресурс] // Аеловая электронная газета «Бизнес Online». 4 июня. URL: http://business-gazeta.ru/text/133773/ [архивировано в WebCite] (дата обращения: 17.06.2015).

Распоряжение Правительства Российской Федерации от 8 декабря 2011 г. № 2227-р. (2012) [Электронный ресурс]// Российская газета. 3 января. URL: http://rg.ru/2012/01/03/innov-razvitie-site-dok.html [архивировано в WebCite] (дата обращения: 17.06.2015).

Смирнова, Е. В., Митрофанова, С. В. (2014) Государственная молодежная политика: региональный аспект // Наука и мир. Т. 2. № 4 (8). С. 130-132.

Стратегия развития научной и инновационной деятельности в Республике Татарстан до 2015 года : Указ Президента Республики Татарстан от 17 июня 2008 г. № УП-293 (2008) [Электронный ресурс] // Электронный фонд правовой и научно-технической информации. URL: http://docs.cntd.ru/document/917029427 [архивировано в WebCite] (дата обращения: 17.06.2015). 
Уразметова, Р. К., Хисматуллин, И. Р. (2015) Основные пути совершенствования молодежной политики в Российской Федерации // АНТРО. № 1 (16). С. 141-150.

Хисматуллин, И. Р. (2014) Государственная инновационная молодежная политика в Республике Башкортостан // Социология науки и технологий. Т. 5. № 1. С. 115-128.

Аата поступления: 15.07 .2015 2.

\section{PARTICIPATION OF YOUTH IN THE INNOVATIVE DEVELOPMENT OF THE ECONOMY: THE CASE OF THE REPUBLIC OF TATARSTAN \\ I. L. SAVELYEV, I. R. NASYROV \\ (Office of the President of the Republic of Tatarstan, Kazan)}

Today the innovative potential of new generations is viewed as one of the most important resources of socio-economic and cultural development.

The article deals with the participation of young people in the innovative development of the country, addressing the example of implementing the state youth policy and support of innovations in the Republic of Tatarstan as a constituent subject of the Russian Federation. We have studied the involvement of young people in the innovative development of the economy, in applied research and in the introduction of high technologies in industry.

The main vector of youth involvement in the innovative development of the economy is set at the federal level. The Strategy of innovative development of the Russian Federation up to the year 2020 has been adopted in Russia, and national programs to support youth entrepreneurship and innovation, including the development of the Skolkovo innovation cluster, are being implemented as well. In Russia's regions, state agencies help identify and promote talented and initiative young people with varying degrees of efficiency.

We point out that the development of the innovation economy of the Republic of Tatarstan is underpinned by a target-oriented approach, which contributes to the involvement of youth in this process. A strategy of socio-economic development up to the year 2030 has been adopted in the region, accompanied by regularly updated target programs which help achieve the objectives. Innovative production infrastructure and business support institutes have been developed since the early 2000s. Taking into account the demographic situation and needs of the developing economy, Tatarstan focuses on the problem of the accumulating human capital. In 2006 the first regional grant program "Algarysh" was launched in Tatarstan to provide money for studying in Russian and foreign institutions of higher education. Measures to stimulate innovative research and development are also implemented jointly by regional and municipal authorities and agencies. They also provide organizational and financial support to youth organizations which assist in creative self-realization and involvement in the innovation sphere of Tatarstan's young citizens.

Youth participation in innovation activities is of common interest for the state and the younger generation. Achieving the creative potential of young people is impossible without systematic support. At the heart of the dynamic development of the innovative economy of Tatarstan and of the successful formation of innovative human capital lies efficient and determined work of the regional authorities.

Keywords: innovations; youth policy; support of talented youth; educational system; infrastructure of innovation; territorial development; Tatarstan; youth of Tatarstan; sociology of youth

\section{REFERENCES}

Antipina, N. L. (2014) Molodezhnaia politika v Rossii i za rubezhom [Youth policy in Russia and abroad]. Akademicheskii vestnik TGAMEUP, no. 2 (28), pp. 115-122. (In Russ.).

Afanasiev, S. and Idiiatullin, A. (2012) Rezidenty «Alabugi» perekupaiut kadry drug u druga [Alabuga residents are outbidding each others' personnel]. Delovaia elektronnaia gazeta "Biznes Online", April 11. [online] Available at: http://business-gazeta.ru/text/57634/ [archived in WebCite] (accessed 17.06.2015). (In Russ.). 
Bariev, M. M. (2009) Molodezhnaia politika v Respublike Tatarstan [Youth policy in the Republic of Tatarstan]. Vestnik Nauchnogo tsentra bezopasnosti zhiznedeiatel' nosti detei, no. 1, pp. 108-109. (In Russ.).

Bolee dvukhsot chelovek v etom godu poluchili granty po programme Pravitel'stva RT «Algarysh» [More than two hundred people this year received grants under the Algarysh program of the Government of the Republic of Tatarstan]. (2014) Ministerstvo obrazovaniia i nauki Respubliki Tatarstan, October 23. [online] Available at: http://mon.tatarstan.ru/rus/index.htm/news/ 349859.htm [archived in WebCite] (accessed 17.06.2015) (In Russ.).

V Kazani otkrylas' XV Rossiiskaia i X Kazanskaia venchurnaia iarmarka [The 15th Russian and the 10th Kazan Venture Fair has opened in Kazan]. (2015) Investitsionno-venchurnyi fond Respubliki Tatarstan, April 24. [online] Available at: http://ivf.tatarstan.ru/rus/index.htm/news/422195.htm [archived in WebCite] (accessed 17.06.2015). (In Russ.).

Vysokie tekhnologii propishutsia $\mathrm{v}$ Tatarstane [High technologies to find a home in Tatarstan]. (2015) Kazanskie vedomosti, no. 81, June 10. [online] Available at: http://kazved.ru/article/61600. aspx [archived in WebCite] (accessed 17.06.2015) (In Russ.).

Doklad Ministra po delam molodezhi i sportu Respubliki Tatarstan Vladimira Aleksandrovicha Leonova na zasedanii Kollegii Ministerstva po delam molodezhi i sportu Respubliki Tatarstan «Opyt i perspektivy realizatsii gosudarstvennoi molodezhnoi politiki v Respublike Tatarstan», posviashchennoi 20-letiiu realizatsii gosudarstvennoi molodezhnoi politiki v Respublike Tatarstan [Report by Vladimir Aleksandrovich Leonov, Minister of Youth and Sports of the Republic of Tatarstan, at the session of the Ministry of Youth and Sports of the Republic of Tatarstan "Experience and Prospects of Implementing the State Youth Policy in the Republic of Tatarstan", dedicated to the 20th anniversary of the implementation of the state youth policy in the Republic of Tatarstan]. (2014) Ministerstvo po delam molodezhi i sportu Respubliki Tatarstan, December 11. [online] Available at: http://mdms.tatarstan.ru/rus/file/pub/pub_283868.doc [archived in WebCite] (accessed 17.06.2015). (In Russ.).

Elkina, M. (2015) V shkol'nuiu programmu predlagaiut vkliuchit' obiazatel'nye puteshestviia [Compulsory travel to be included in school program: A suggestion]. Izvestiia, June 9. [online] Available at: http://izvestia.ru/news/587435 [archived in WebCite] (accessed 17.06.2015) (In Russ.).

Ilinskiy, I. M. (2001) Molodezb' $i$ molodezhnaia politika [Youth and youth policy]. Moscow, Golos Publ. 696 p. (In Russ.).

Imennye stipendii mera Kazani vruchili v stolitse Tatarstana [Scholarships of the mayor of Kazan were awarded in the capital of Tatarstan]. (2014) IA "Tatar-inform", December 24. [online] Available at: http://tatar-inform.ru/news/2014/12/24/435825/ [archived in WebCite] (accessed 17.06.2015). (In Russ.).

Kantyshev, P. (2015) Dognat' i peregnat' za 10 let [To catch up and overtake in 10 years]. Vedomosti, April 5. [online] Available at: http://vedomosti.ru/newspaper/articles/2015/04/05/dognat-i-peregnat-za-10-let [archived in WebCite] (accessed 17.06.2015). (In Russ.).

Kogai, E. A. and Atanasov, A. G. (2013) Sotsial'noe proektirovanie v regional'noi molodezhnoi politike [Social project planning in the regional youth policy]. Uchenye zapiski. Elektronnyi nauchnyi zburnal Kurskogo gosudarstvennogo universiteta, no. 4 (28), pp. 271-277. [online] Available at: http://scientific-notes.ru/pdf/033-039.pdf [archived in WebCite] (accessed 17.06.2015). (In Russ.).

Lukov, V. A., Lukov, S. V. and Pogorskiy, E. K. (2014) Innovatsionnyi potentsial novykh pokolenii i molodezhnaia politika na sovremennom etape razvitiia obshchestva [The innovative potential of the new generations and youth policy at the present stage of development of society]. PolitBook, no. 2, pp. 6-18. (In Russ.).

Moskovtseva, E. A. (2011) Molodezhnaia politika na regional'nom urovne [Youth policy at the regional level]. Uchenye zametki TOGU, vol. 2, no. 1, pp. 46-52. (In Russ.).

Ob utverzhdenii Strategii sotsial'no-ekonomicheskogo razvitiia Respubliki Tatarstan do 2030 goda. Zakon Respubliki Tatarstan № 40-ZRT ot 17 iunia 2015 g. [On approval of the Strategy of socio- 
economic development of the Republic of Tatarstan until 2030. Law of the Republic of Tatarstan No. 40-ZRT of June 17, 2015]. (2015) Portal pravovoi informatsii Respubliki Tatarstan, June 17. [online] Available at: http://pravo.tatarstan.ru/rus/gossov/zakon.htm/?npa_id=4431 [archived in WebCite] (accessed 18.06.2015). (In Russ.).

Osoboi ekonomicheskoi zone trebuiutsia «spetsy» [Special economic zone requires "specialists"]. (2015) Delovaia elektronnaia gazeta “Biznes Online”, June 4. [online] Available at: http://businessgazeta.ru/text/133773/ [archived in WebCite] (accessed 17.06.2015). (In Russ.).

Rasporiazhenie Pravitel'stva Rossiiskoi Federatsii ot 8 dekabria 2011 g. № 2227-r [Order of the Government of the Russian Federation, No. 2227-r, December 8, 2011]. (2012) Rossiiskaia gazeta, January 3. [online] Available at: http://rg.ru/2012/01/03/innov-razvitie-site-dok.html [archived in WebCite] (accessed 17.06.2015). (In Russ.).

Smirnova, E. V. and Mitrofanova, S. V. (2014) Gosudarstvennaia molodezhnaia politika: regional'nyi aspect [State youth policy: The regional aspect]. Nauka $i$ mir, vol. 2, no. 4 (8), pp. 130-132. (In Russ.).

Strategiia razvitiia nauchnoi i innovatsionnoi deiatel'nosti v Respublike Tatarstan do 2015 goda: Ukaz Prezidenta Respubliki Tatarstan ot 17 iunia 2008 g. № UP-293 [The development strategy of research and innovation activities in the Republic of Tatarstan up to the year 2015: Decree of the President of the Republic of Tatarstan of June 17, 2008 No. UP-293]. (2008) Elektronnyi fond pravovoi i naucbno-tekbnicheskoi informatsii [online] Available at: http://docs.cntd.ru/document/917029427 [archived in WebCite] (accessed 17.06.2015). (In Russ.).

Urazmetova, R. K. and Khismatullin, I. R. (2015) Osnovnye puti sovershenstvovaniia molodezhnoi politiki v Rossiiskoi Federatsii [The main ways of improving youth policy in the Russian Federation]. ANTRO, no. 1 (16), pp. 141-150. (In Russ.).

Khismatullin, I. R. (2014) Gosudarstvennaia innovatsionnaia molodezhnaia politika v Respublike Bashkortostan [The state innovative youth policy in the Republic of Bashkortostan]. Sotsiologiia nauki i tekbnologii, vol. 5, no. 1, pp. 115-128. (In Russ.).

Submission date: 15.07.2015.

Савельев Игорь Аеонидович - кандидат социологических наук, начальник Управления государственного протокола Президента Республики Татарстан. Адрес: 420014, Россия, г. Казань, Кремль, Аппарат Президента Республики Татарстан. Тел.: +7 (843) 567-87-46. Эл. адрес: Igor.Savelev@tatar.ru

Насыров Ильдар Рустамбекович - доктор политических наук, заведующий отделом международного сотрудничества Аепартамента внешних связей Президента Республики Татарстан. Адрес: 420014, Россия, г. Казань, Кремль, Аппарат Президента Республики Татарстан. Тел.: +7 (843) 567-88-03. Эл. адреc: Ildar.Nasyrov@tatar.ru

Savelyev Igor Leonidovich, Candidate of Sociology, Head of the State Protocol, the Office of the President of the Republic of Tatarstan. Postal address: Office of the President of the Republic of Tatarstan, Kremlin, 420014 Kazan, Russian Federation. Tel.: +7 (843) 567-87-46. E-mail: Igor.Savelev@tatar.ru

Nasyrov Ildar Rustambekovich, Doctor of Political Sciences, Head, Office of International Cooperation, Department of Foreign Affairs, Office of the President of the Republic of Tatarstan. Postal address: Office of the President of the Republic of Tatarstan, Kremlin, 420014 Kazan, Russian Federation.Tel.: +7 (843) 567-88-03. E-mail: Ildar.Nasyrov@tatar.ru 